\title{
Chinese art museums: organisational models and roles in promoting contemporary art
}

\section{Ornella De Nigris}

International Communication of Chinese Culture

ISSN 2197-4233

Int. Commun. Chin. Cult

DOI 10.1007/s40636-018-0113-x
International

Communication of Chinese Culture

An Official Journal of Academy for International Communication of Chinese Culture

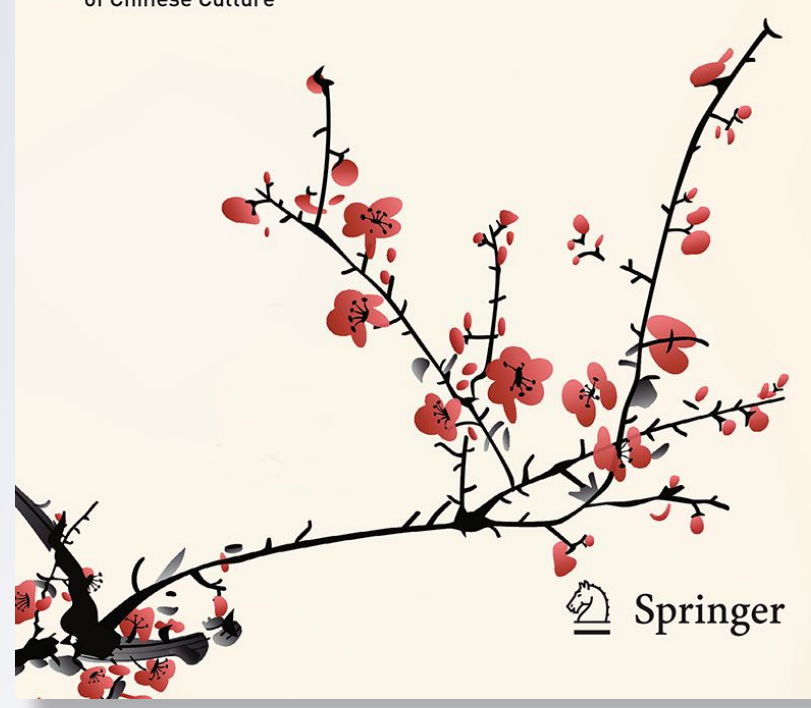


Your article is protected by copyright and all rights are held exclusively by Academy for International Communication of Chinese Culture and Springer-Verlag GmbH Germany, part of Springer Nature. This e-offprint is for personal use only and shall not be selfarchived in electronic repositories. If you wish to self-archive your article, please use the accepted manuscript version for posting on your own website. You may further deposit the accepted manuscript version in any repository, provided it is only made publicly available $\mathbf{1 2}$ months after official publication or later and provided acknowledgement is given to the original source of publication and a link is inserted to the published article on Springer's website. The link must be accompanied by the following text: "The final publication is available at link.springer.com". 


\title{
Chinese art museums: organisational models and roles in promoting contemporary art
}

\author{
Ornella De Nigris ${ }^{1}$ (D)
}

Received: 14 March 2017/Revised: 26 January 2018/ Accepted: 22 February 2018

(C) Academy for International Communication of Chinese Culture and Springer-Verlag GmbH Germany, part of Springer Nature 2018

\begin{abstract}
The museum devoted only to art is a relatively novel concept in China, nevertheless, in the last years, thousands of contemporary art museum have flourished all over in the country. This phenomenon follows a more general ongoing renovation process of the entirety of the national art institutions system, which has started in the 1990s. This paper aims to outline a general framework of the most recent development of contemporary art museum in China, in order to answer some questions: which kind of art museum exhibits Chinese contemporary art, and consequently, what is their role in promoting this art? Finally, considering the host of problems in the management and long term curatorial planning, it aims at examining whether it is possible to identify a sustainable way to manage contemporary art museums in China. This analysis has been drawn following a field research on Chinese contemporary art museums, focussing on museums observations and interviews held with stakeholders (artists, museum directors and curators) involved in the museum work in some of the major cities of China.
\end{abstract}

Keywords Contemporary Chinese art · Art museum - Cultural sustainability · OCAT Shenzhen $\cdot$ Museum fever

\section{Introduction}

In the last 30 years, Chinese museum system is enjoying un precedent development, and different typologies of collections are rising at national, provincial and municipal level, supported directly or indirectly by national and local governments, in the most important cities but also in the erxian and sanxian chengshi二线, 三线

Ornella De Nigris

ornelladenigris@gmail.com

1 Sapienza University of Rome, Rome, Italy 
城市 second and third tier cities. According to the State Administration of Cultural Heritage, by 2011 there were 3589 museums in China, one for every 380,000 people (Lu 2014, p. 206), a number which has continued to grow considerably, reaching 4165 registered museums in 2015 ( $\mathrm{Li} 2014$ ).

According to professor Jeffrey Johnson, within what he identifies with 'museumification' of China, the $2 \%$ of these museums are dedicated to contemporary art (Johnson 2013) and this percentage is constantly increasing. Considering this growing interest in collecting contemporary art, this paper aims to outline a general framework of the development of contemporary art museums in China, in order to answer the following key questions: which kind of art museum exhibits Chinese contemporary art, and consequently, what is their role in promoting this art? Finally, considering the host of problems in the management and long term curatorial planning, it aims at examining whether it is possible to identify a sustainable way to manage contemporary art museums in China. This analysis has been drawn following a field research on Chinese contemporary art museums, focussing on museums observations and interviews held with stakeholders (artists, museum directors and curators) involved in the museum work in some of the major cities of China.

In recent years, sustainability_covering three aspects: environmental, economic and social-has emerged as a concept adopted internationally in museum field studies and in the Chinese art world. The International Council of Museums, for example, used the slogan "Museums for a sustainable society" for International Museum Day in 2015, and some influential curators in China, including Nikita Yingqi Cai, curator at the Guangdong Times Museum in Guangzhou, are stimulating debate on the topic. She defines sustainability as "building up and strengthening a belief in contributing, for free, to others and society, and the urge to diversify practices of cultural production" (Cai 2012, pp. 34-35).

\section{China and the art museum}

The museum devoted only to art is a relatively novel concept in China; its history can be traced back to the 1940s, when the first art museums started to appear in the country. One of those examples is Jiangsu Art Museum (formerly Jiangsu National Art Gallery), founded in Nanjing in 1936. When talking about the traditional view of the art museum, it can be argued that, due to this brief history, there exists no real art museum culture in China. Indeed, the general understanding is that museums, through exhibiting history and cultural artefacts, are the basis of patriotic education, and "vehicles for official [...] and sometimes also popular, identity discourse" (Vickers 2007, p. 366). Indeed, history museums were the most common in the period after the founding of the People's Republic of China in 1949, serving the socialist purpose to educate the masses through history. For this reason, as highlighted by scholars Hua Jianguo and Gao Min, today the bowuguan (museum par excellence) and the meishuguan (art museum) are regarded as two kinds of cultural organizations of a totally different nature, being the latter regarded as a 
commercial and temporary exhibiting location rather than a cultural and stable organization (Hua and Gao 2010, p. 89).

Indeed, in the spoken language, the Chinese word meishuguan can vaguely refer to two kinds of institutions: 'art gallery' 画廊 hualang-a for-profit exhibiting space, generally related to contemporary art, and 'museum of art' 艺术博物馆 yishu bowuguan or 艺术馆 yishuguan一a museum of art, a non-profit art institution, generally dedicated to modern art. Consequently, the meishuguan sometimes is considered as an institution of minor importance when placed alongside the bowuguan.

Following a more general and ongoing renovation process of the entirety of the country's national art institutions, in recent years the art museum system has been enjoying unprecedented development, and deserves close attention. Since the late 1990s, thousands of meishuguan began flourishing all over in the country, launching the so-called 'museum fever' (meishuguan re 美术馆热), which still exists today. The first wave of this fever in the 1990s, took place when most private collectors started to establish contemporary art museums in cities large and small across China. Some of these earliest examples are the Chengdu Shanghe Museum (Chengdu Shanghe meishuguan 成都上河美术馆) opened in 1998, followed by two others in the same year: the Shenyang Dongyu Museum (Shenyang Dongyu meishuguan 东宇美术馆) and the Tianjin Teda Museum (Tianjin Taida meishuguan 泰达美术馆). The opening of these meishuguan, funded by local entrepreneurs, marked an important stage in the development of the art museum system. They were innovative in their purpose of exhibiting, researching and collecting young contemporary artists within an institutional framework-the art museum, whose purpose was basically not for profit (Wang 2010).

Works by Fang Lijun, Zhang Xiaogang, Wang Guangyi indeed, were collected and shown in the three meishuguan. The Dongyu Museum also collected for the first time video and installation artworks by artists Wang Jianwei and Li Yongbin (Li 2007). The historical importance of these art museums lies not only in having supported young contemporary artist, but also in having fostered the formation of those artistic circles and professional figures, which in the future would have become among the major protagonists of the Chinese art scene. Such examples are curators like Li Xianting and Huang Zhuan who collaborated with Shanghe Museum (Chen et al. 2015, p. 49).

A second moment in the boom of the foundation of meishuguan took place around mid 2000s. This can be considered as a different stage in the development of the meishuguan, because new actors become the supporters of this growth, i.e. big real estate companies. Compared to the afore-mentioned art museums born around the end of 1990s, these meishuguan showed different purposes and features. Indeed, after the real estate overbuilding of the years 2001-2004, big buildings remained unsold and in coincidence with the bourgeoning of contemporary Chinese art market, some companies decided to invest in art and to dedicate those spaces to exhibit contemporary works. These art museums were not the product of efforts provided by single investors, but rather founded by big companies, with big economic potentials, as explained by Wang Naming, critic and curator and actual director of Himalayas Museum, during a personal interview: 
[...] real estate companies owned big spaces, and all that they needed was to anticipate a little money, which is not a big problem. Companies also have their marketing, advertising fees and at that time, they put a little bit of their own publicity costs into the field of contemporary art, and then of course started to organize the exhibitions.

Examples of this kind of museums, are the Today Art Museum in Beijing (Jinri meishuguan 今日美术馆) and the Himalayas Art Museum in Shanghai (Ximalaya meishuguan 喜玛拉雅美术馆, formerly the Zendai Museum) which were established in 2002 and 2005 respectively by two big real estate companies, Anteo Corporation and Zendai Group.

The spread of a new typology of art museum since 2010 led to a third wave of museum fever. The Chinese terms to indicate this kind of museum are various, but the most common are: minban gongzhu 民办公助 and gongban minying 公办民营 (hereafter referred to as minying) and in this analysis represent two different variants within the same category. Minban gongzhu literally means 'run by local people and subsidized by the state', while gongban minying means 'commissioned by the government and administered by the people or by enterprises'. It is beyond the aims of this paper to analyse this difference from a juridical perspective, but it will endeavour to highlight the echoes on collecting and exhibiting art.

The minying concept derives from economics, and refers to a new kind of enterprise which started to spread across China after 2002. In order to simplify, minying can be defined as a public-private partnership in public utilities (Yang 2006). This approach started to disseminate, and to extend to other fields, including economic and cultural institutions. Naturally, museums were not an exception. Today, the minying organizational model, with a mix of state and private management, is the most widespread kind of art museum in China.

\section{Between private and state-owned museums}

In order to address the issues mentioned above, this analysis must focus on the identity of art museums of China. When speaking about different museum organizational models, it must be considered that, as Yang Chao, director of the Xi'an Art Museum (Xi'an meishuguan 西安美术馆) states, the two forces leading the growth of art museums are the Chinese government and the development of the private sector (Yang 2014).

The abundance of economic resources, governmental and also private, and the renewal of official system led to the blurring of the line between state (usually associated with the political bureaucracy) and private (tied to the logic of the market), and the birth of hybrid realities. So, if on the one extreme there is the museum wholly run by the state and on the other there is the museum wholly private, the increasing variety of intermediate typologies, such as the aforementioned minying, grafts private elements onto public elements and vice versa. This sometimes makes the typology of a meishuguan difficult to identify. In addition to the problem of identifying an art museum from a formal perspective, we should also 
consider the problems raised when public officers and positions in the private sector are combined. It can happen, for example, that the director of a private museum holds a public office at the same time: this is the case of Zhang Zikang, former director of the Today Museum in Beijing, as well as Deputy Director of Cultural Affairs of the Autonomous Region of Xinjiang.

These forces have shaped different organisational models, which can be identified as follows: state-run museums (guoli meishuguan 国立美术馆), private museums (sili meishuguan 私立美术馆), the above mentioned minying, and the collections established by foreign collectors within China. One example of collections entirely funded by foreign collectors is the Ullens Center of Contemporary Art (UCCA) in Beijing, founded in 2007 by Guy and Miriam Ullens and located inside the 798 Art District. ${ }^{1}$

The guoli meishuguan include for example the National Art Museum of China NAMOC 中国美术馆 Zhongguo meishuguan in Beijing (open to the public in 1963), and the Shanghai Art Museum 上海美术馆 Shanghai meishuguan in Shanghai (1956-2012). These museums are non-profit cultural institutions, and are funded and fully financed by the Chinese government. The NAMOC, for example, considered "a national cultural landmark since after the foundation of New China" (National Art Museum of China) is directly supported by the central government, under the leadership of the Ministry of Culture. State-owned museums include state, provincial, regional and municipal levels, and the director must be a government employee with rank. Some of these museums were established in the years following the founding of the People's Republic of China, and none of them are completely dedicated to collecting or exhibiting contemporary art, rather focussing on modern art masterpieces or folk art.

State-owned art museums have started to flourish since the 1980s, especially in the south-west regions, following the economic development of the coast. Thus cities like Shanghai, Guangzhou and Shenzhen have gradually become new cultural hubs, with a number of museums funded in a short space of time. Some examples are: the Liu Haisu Art Museum 刘海粟美术馆 Liu Haisu meishuguan (1995), the Zhu Qizhan Art Museum 朱屺瞻艺术馆 Zhu Qizhan yishuguan (1995) and the Duolun MOMA Museum of Modern Art 多伦现代美术馆 Duolun xiandai meishuguan (2003) funded in Shanghai; the Guangdong Museum of Art GDMOA 广东美术馆 Guangdong meishuguan (1990) and the Guangzhou Museum of Art 广 州艺术博物馆 Guangzhou yishu bowuguan (1995) in Guangzhou; the Shenzhen Art Museum 深圳美术馆 Shenzhen meishuguan (1987) and the He Xiangning Art Museum 何香凝美术馆 He Xiagning meishuguan (1997) both located in Shenzhen.

Private art museums are established by domestic business interests or by some rare philanthropic collector. Actually, Long Museum 龙美术馆 Long Meishuguan (2013) in Shanghai is the most well-known example of a private art museum, created according to the personal taste of the collector and businessman Liu Yiqian.

\footnotetext{
${ }^{1}$ In this article, these collections will not be covered, because the focus is on the relationship between the Chinese state and private sectors in the management of museums. A discourse on foreign collections focussing on contemporary Chinese art would deserve a further study to do it justice, so it will not be covered in this paper.
} 
These collections are born according to the personal taste of the collector or funded by big corporations investing in art. According to statistics, by 2014 there had been more than 900 private museums registered at the local administration offices, and this would represent $20 \%$ of the totality of museum in China (Liu 2015). Private museums started to appear in China by the late 1990s, when some of them obtained to be registered as 'non-enterprise social organizations'. The museum which paved the way for all private art collections in China was the Yan Huang Art Museum 炎黄艺术馆 Yan Huang Yishuguan in Beijing, initiated in 1986 by the artist Huang Zhou, and opened to the public in 1991. This was the first nongovernmental art collection to be recognized by the government and to obtain a legal status (Song 2008). Since then, many private art collections opened their doors to become public museums, such as the aforementioned Shanghe, Dongyu and Teda.

Looking at the brief history of the earliest Chinese private art museums, it is not hard to discover that most of them, especially those belonging to a single collector, are often confronted with economic difficulties due to a lack of capital, and are forced to close or need capital injection from other investors. Examples of this kind are those born during the first wave of the fever of the 1990s, such as the aforementioned Chengdu Shanghe Museum, Shenyang Dongyu Museum and Tianjin Teda, forced to close soon after their opening having displayed only a few exhibitions. The Yan Huang Art Museum was about to close due to bankruptcy, but in 2007 the China Minsheng CMBC Bank designated an investment for the museum, and "forged [it] into a first-rate public welfare museum" (Chen et al. 2015, p. 253). This kind of fusion can sometimes determine the changing of the museum's status, in this case Yan Huang Art Museum has shifted from private to minying. This flexibility in some cases contributes to making the single typologies and set of characteristics difficult to distinguish.

A museum belonging to minying category holds projects and exhibitions which occasionally are in collaboration with other state-run museums or official art institutions. They do not receive regular funding from the government, but are listed as non-profit institutions separately from the private ones, which from a juridical point of view are not recognized as non-profit cultural institutions. If on the one hand these kinds of museums can work better outside the direct control of the government and within a more flexible system, on the other hand they constantly need to find sponsors and capital, and this depends upon the influence of the museum's director and how able he or she is to find sponsors. The museum of the minying type is the next closest to what is conceived to be a private art museum, and together with the sili are the most widespread throughout China since the 1990s.

During the field research, when talking about museums' statuses and different approaches to art, most of the interviewees did not make a major distinction between sili and minying types. But Ms. Zheng Yan, former vice director of Today Art Museum in Beijing, stated that the former is 'private' and the latter is 'public'. Indeed, according to the Chinese way of thinking, private museums belong to a single person or private entity, while public museums are those funded by companies which 'belong to the people'. The word 'public' (gongzhong 公众 in Chinese) here differs from its correspondent in English, where 'public' is associated 
with the state. In China, the 'public museum' belongs to people and society, and it is different from the 'state-run', which is owned and managed by the Chinese government, but is not private. Minying type museums mean 'belonging to the society' and generally refers to a non-profit organization founded by large companies, such as those involved in real estate or cultural industries. In theory, these kinds of museums can be recognized as cultural institutions by the government, and are intended to be non-profit. Rather, the sili kind still represents a private and for-profit exhibiting space.

The Shenzhen OCT Contemporary Art Terminal (OCAT Shenzhen) is another example of this kind of art museum. Founded in 2005 as a division of He Xiangning Museum in Shenzhen, it is administrated by the Overseas Chinese Affairs Office 国 务院侨办 Guowu yuanqiao ban, and a part of its finances come from the Overseas Chinese Construction Corporation (a state-run corporation). ${ }^{2}$ The Xi'an Art Museum, is another such example. Founded in 2009 and run by Yang Chao, a businessman who was charged to run the museum as part of the Qujiang New District planned by the Xi' an local government. In this case, the museum is stateowned but run by a person from the private sector.

\section{Which role in promoting contemporary art?}

The different kinds of institution analysed above, as already mentioned, have different approaches to collecting and exhibiting works of art, and consequently they play different roles in the promotion of contemporary art. It is commonly accepted that the museum is a non-profit institution which serves society and is devoted to collect, preserve, research, publish, and exhibit the heritage of a culture. Making exception for the Power Station of Art in Shanghai 上海当代艺术博物馆 Shanghai dangdai yishu bowuguan none of the national art museums of China are totally dedicated to collecting contemporary art. Generally speaking, the permanent collection focuses on modern and traditional art. Most of the works date from the twentieth century to the 1980s or early 1990s (rarely), including great masters of traditional ink painting, calligraphy, sculpture, ceramics, folk art, and modern variations on traditional Chinese painting.

The permanent collection of the National Art Museum of China, for example, houses more than 100,000 works representative of various periods of Chinese art history, ranging from the 19th century to the present day. It also includes ancient paintings and calligraphy and also some western art masters, like Picasso. Among the Chinese great masters' works, there are masterpieces by Ren Bonian, Wu Changshuo, Huang Binhong, Qi Baishi, Xu Beihong, Liu Haisu, Li Keran, Wu Zuoren, and Wu Guanzhong. The contemporary art collection includes just a few works, for example Luo Zongli's oil painting Father (1980).

\footnotetext{
2 The Overseas Chinese Affairs Office is the administrative office responsible for liaising with overseas Chinese residing abroad or returning to China. The Committee of Overseas Chinese Affairs, its forerunner, was established in 1949; He Xiangning, the wife of Liao Zhongkai, served as its first head from October 1949 to April 1959 (Peterson 2012, p. 78).
} 
The Guangdong Museum of Art aims at collecting recent and contemporary works of art by artists living in China, especially focusing on Guangdong Province. The permanent collection also includes the more traditional artistic expressions, including folk art, lacquer painting, photography, poster and comics. It also has an emphasis on the coastal areas of Southeast China. Among the contemporary works collected are Zhang Dali's acrylic painting AK47(P10) (2009) and Wang Qingsong's Follow you (2013). As for the Shanghai Art Museum collection, it covers the various stages of Chinese art development in the 20th century. Also in this case, contemporary artworks function as a complement to the main collection; there are, for example, works by $\mathrm{Gu}$ Wenda, Liu Ye, Zhang Xiaogang and Fang Lijun.

State-run museums, like the afore mentioned National Art Museum of China, the Guangdong Museum of Art and the Shanghai Art Museum, tended to open their doors to contemporary artworks in the early 2000s, and in two distinct ways: by acquiring classic works of contemporary art, as described above, but most frequently hosting regular great exhibition projects. Great exhibitions include, for example, the Beijing International Art Biennale, held from 2003 at NAMOC; the Shanghai Biennale held from $2000^{3}$ at Shanghai Art Museum and the Guangzhou Triennial, held from 2002 at GDMOA. As for the artistic contents of these biennial projects, they usually do not make a close investigation in the controversial and dynamic debate occurring in contemporary art, but rather function as retrospectives of recent works of art or surveys on orthodox official art (Wang 2008, pp. 20-31).

The first Guangzhou Triennial, for example, titled Reinterpretation: A Decade of Experimental Chinese Art, aimed at creating an "historic review and academic interpretation of the experimental Chinese art since the 1990s" (Biennial Foundation 2002), and mainly exhibited works of the experimental art produced in China between 1990 and 2000. This characteristic seems to be in contrast with the meaning of the Biennial, whose role in contemporary global art world has become to exhibit new trends and to show emerging artists, engaged in a more sociallyoriented debate. This apparent openness to contemporary art demonstrated by stateowned art museums can be interpreted as a strategy for cultural competitiveness, adopted in order to involve the visitor in more attractive art projects and to endow Chinese cities with modern touristic appeal.

The private and public museums' permanent collection, if one exists, is generally built according to the personal tastes of the collector or market value, focussing on modern and contemporary, Chinese or international works of art. The Long Museum collection, which has made many acquisitions at international and national art auctions since the 1990s, has put together a wide collection, including works by internationally renowned artists such as Qiu Zhijie, Huang Yongpin, and Xu Bing. But Liu Yiqian and his wife Wang Wei's collection doesn't seem to be very specifically centred on one direction, since it ranges from antiquities, works of art from the revolutionary propaganda as well as contemporary Chinese art. Their Long

\footnotetext{
3 The first edition of the Biennale was in 1996, but here I consider the third Shanghai Biennale of 2000 as a turning point (De Nigris 2016). Starting from 2012, the Biennial has changed its location, and is hosted by Power Station of Art, in Shanghai.
} 
Museum, born in 2012, is "showcasing a meticulously selected version of élite and sovereign of Chinese art history" (Chun 2014, p. 22) and their main mission is to acquire and repatriate major historical and contemporary works of art.

There are also examples of museums not only dedicated to collect, but also to research and exhibit contemporary artists and practices. One such example is OCT Overseas Contemporary Art Terminal, which will be analysed in the next paragraph as a case study.

\section{Major problems in the management of the art museum}

During this field research, when subjects have been asked "what do you think of the Chinese art museum system?", some of the stakeholders answered that, in their opinion, Chinese museums are searching for their own path; others replied that in China there are no real museums of contemporary art, because, although there are many meishuguan, unfortunately they are not managed as cultural institutions, but rather as cultural industries, without a precise cultural mission or long-term curatorial plan. Actually, both these interpretations can summarize some of the major issues related to the museum system, which remains immature and affected by structural problems.

The collection is to be considered the 'Achilles' heel' of most non-governmental museums - but sometimes also involve smallest governmental local collections, which normally face financial difficulties in building a specific thematic collection. It is not uncommon that the museum's building is constructed initially, with the collection only coming at a later date. As a result, works are acquired randomly, without a long-term curatorial programme, and sometimes the permanent collection is small and not coherent. Some of the newer museums do not even have a permanent collection, acting as kunsthalle, as for example the Guangdong Times Museum in Guangzhou 广东时代美术馆 Guangdong Shidai Meishuguan. Moreover, meishuguan do not share a common collection registration system, and since they are not bound by official regulation, the standards in cataloguing the items are unclear, differs from region to region, and even from museum to museum (Fu 2016). ${ }^{4}$

One of the most striking aspects of the art museum system is a lack of an overarching national policy. For example, state museums and minban gongzhu differ from other types in one crucial aspect, they are regulated by a number of laws which provide for registration at the public office, and are thus recognized in local government as non-profit institutions. Moreover, state-owned museums are not administered by a unique centralized administrative body, therefore some meishuguan can depend on Publicity Department, others on the Cultural Relic Bureau, thus generating a fragmentation in the museum work. These structural

\footnotetext{
${ }^{4}$ This problem led the Ministry of Culture to carry out a census, between 2013 and 2015, with the aim of finding out the situation of the collections in Chinese art museums. On this occasion two important documents were completed, Working standards of the census of collections in art museums of China 全国 美术馆藏品普查工作标准 and Working procedures of the census of collections in art museums of China 全国美术馆藏品普查工作规程 (Fu 2016).
} 
problems not only affect the cultural quality of these museums, but could also represent a fragmentation of it, because a network of art museums and professionals would address common issues and seek solutions together.

From the financial point of view, the guoli type museums enjoy substantial funding from the government. According to a report by $\mathrm{Zhu} \mathrm{Di}$, deputy director general of the Department of Arts of the Chinese Ministry of Culture, between 2010 and 2012, the government allocated 16.5 million yuan to support 112 projects in art museums. Only 15 percent of these funds were allocated to private museums, which instead must rely on private donations to survive (Sun 2013). Donations are another central issue, because China lacks a comprehensive and coherent tax structure allowing for donations to non-profit institutions. In theory, according to the Public Welfare Donations Law, donations to not for profit organisations are tax exempt. In practice, however, art museums that are legally registered as not for profit organizations, must still apply separately to the tax bureau in order to obtain tax benefits. Furthermore, there is little familiarity with income tax deductibility for donations among both tax authorities and donors. Moreover, contributions to those not for profit meishuguan which are not registered are not tax deductible (Irish 2004).

According to Chinese art critic Wang Nanming, the economic difficulties of the smallest museums depend on the fact that China lacks a well-structured non-profit foundations system, and the complexity of the tax and donations system, discourages donations (Wang 2011, pp. 16-27). This affects the continuity of curatorial projects, and also the independence of the curators, who are forced to seek funding externally. As a result, most of the museums are registered at commercial and industrial offices as a 'society for cultural communication'. Only few private museums have been recognized with institutional status, as is the case of minying which have been promoted to minban gongzhu status.

Some museum directors and managers have implemented various strategies to solve this problem, such as renting their spaces to hold temporary exhibitions, although very often this results in a messy and confusing sequence of temporary exhibitions without a curatorial logic, influencing the credibility and development of the museum. The majority of these new museums - especially the private ones-are forced to close after a few years of activity, such as the aforementioned cases of Chengdu Shanghe Museum, Shenyang Dongyu Museum and Tianjin Teda, or fail in their cultural mission.

Today, shortage of funding is perhaps the principal problem affecting the sector, and in a deeper analysis this can be considered a consequence of the inadequate understanding of what an art museum should be, especially in the private sector. Many investors might think that an initial injection of money is enough to build and run a museum, using art and cultural promotion as a status symbol. It has been common for China's nouveau riche to assume the role of art patrons and philanthropists, with the conviction that money can buy culture and social prestige. Perhaps this is the reason why many seem to believe that to establish a museum is to simply build one, while ignoring that it is the content and the collection that makes a museum such. 
The problem of shortage of funding involves all typologies of museums, including the state-owned ones. We can consider, for example, the case of the PSA in Shanghai. Although the government paid the $\$ 64$ million to convert the 450,000 square-foot space into a museum, the institution-like many other public museums today-still struggles to find enough money for operations, including building a substantive collection. Many museums consequently act more as for-profit than cultural institutions, and artworks in the permanent collection are acquired randomly and following market value. Museums have difficulty in building a collection on the basis of a curatorial plan, without mentioning the almost absent research element, as well as planning long-term exhibitions, educational programmes and exchanges or artists residencies. Some of these museums do not even have a permanent collection - a strong contradiction with the very nature of the museum, which by definition is the place of art conservation.

In addition to the problem of the collection, the lack of long-term curatorial and management planning is another central issue, together with other consequences, like a shortage of professional staff training, including curators, art handlers, collection managers, and research assistants. The only institution with a curatorial studies program that includes contemporary art is the Central Academy of Fine Arts in Beijing, but most of its graduates prefer to go to work for auction houses and galleries. Some, like the Long Museum or the Today Art Museum, usually invite guest curators for temporary exhibitions and appoint distinguished members as academic advisors, in order to be considered as institutions engaged in the contemporary art world. But if we look under the surface it is not difficult to discover that research is almost as absent as the exploration of an innovative kind of exhibition.

\section{Sustainability as a future perspective?}

This framework reveals a strong contradiction with the primary mission of the traditional museum, which is to research, collect, and display works of art, and to preserve them for the future. It is necessary to find solutions and a new way of thinking: museums should not only find a sustainable way to execute long term planning, they must also remember its role in raising public awareness about the need for present and future society. Chinese museums, with their suggestive architecture and magnificent projects, nevertheless seem to behave like "white cubes", to use the words of Brian O'Doherty (1999) like aseptic and sterile shells, detached from the need of society and contingences of real life.

Today, this kind of museum is unsustainable-both ideologically and practically. Ideologically, because the museum, by definition, is concerned with the needs of the future, so it is also in a certain way contemporary art and an expression of human creativity; art's visual form simplifies concepts and has the power to awake people conscience. Practically, because a museum not only needs sustainable planning, economically and ecologically, but it also should make its collection accessible and comprehensible to people. Thus, it seems urgent to advocate a shift in the museum field, from the predominance of the appearance, to a more ethical and engaged 
approach, that is less wasteful, more cooperative and uses resources in a way that respects living systems. A new museum has to respond to the demands for social space, thus becoming a place of interaction for the public; art, and all the related stakeholders, artists and curators have a duty to find new ways to make, display, exhibit and interpret the present.

In present China, only a few managers, directors and curators are engaged in seeking solutions in order to identify this sustainable way. Mostly they are concerned with the economic aspect, due to the need to find financial resources to survive. Many of them see in the establishment of non-profit foundations the solution for the economic problem. This is the case of the aforementioned Wang Nanming. There are also examples of museum directors or curators attempting to raise awareness of sustainability in the cultural mind-set by organizing art related projects. But we can say that these are isolated cases and today there are very few examples, if any, of sustainable management of museums.

The great boom of museums does not necessarily correspond to a higher standard of curatorial policy and management. Therefore, to answer the initial question about the role of the museum in promoting contemporary art, in the light of what has been said about sustainability, it can be assumed that very few museums are engaged in developing new programmes focussed on research and trying to stimulate debate in contemporary art. The case study that will be analyzed in the next section of this paper, in a sense, wants to answer the question of whether the curatorial policy of contemporary art museums operates in a coherent and sustainable way, and if in them it is possible to trace a perspective for a sustainable development of the Chinese art museum sector.

\section{OCT contemporary art terminal OCAT: a case study}

The He Xiangning Art Museum in Shenzhen was established in the 1990s as a nonprofit institution, run by the state cultural company, the Huaqiao, and dedicated to the artist namesake, He Xiangning. In the following years, the company Huaqiao Overseas Chinese restructured an area located in the industrial area east of the city, and decided to found in this place a tourist-cultural park, the OCT. In 2004, part of this area became devoted to art, and on January 28, 2005 the Overseas Contemporary Art Terminal, the first non-profit organization linked to a national museum, was born. The English name derives from the acronym OCAT Overseas Chinese Town, OCT.

The museum was born, like many urban projects in China, with a clear will to create an artistic hub similar to the 798 Beijing district, to convey contemporary urban culture and even to attract international influencers and investment. On July 2012, the OCAT museum became independent from the He Xiangning Museum, and registered with the local authorities as a non-profit organization, specializing in art (fei yinglixing meishuguan 非营利性美术馆). Today, in Shanghai, Beijing and Wuhan, there are detachments of OCAT. The current administrative director of the OCT Art Terminal is Luan Qian (from 2015). 
The mission of the museum is to integrate national and international resources for the promotion of contemporary Chinese art, but at the same time to stimulate exchange projects. Thanks to the numerous art projects, exhibitions, forums and artist residencies programmes, the museum wants to be a reference not only for Chinese but also for international artists, thus deriving the name Art Terminal. The OCAT collection includes not only contemporary Chinese works, but also international works acquired in most cases through artists' donations. Among the earliest works acquired are Huang Yongping's Bath plan and Lin Yilin's The 11th 5year plan. These works were collected in 2005 and were among the first in the permanent collection, having been part of the international sculpture exhibition organized by He Xiangning Museum. The museum also collects works from emerging experimental artists.

In addition to focussing on visual art, OCAT also promotes other forms of artistic expression, such as theatre shows, musical performances, film, video and multimedia presentations, thus embodying the multidisciplinary nature of contemporary art and museums. Even before the birth of OCAT, He Xiangning Museum had launched a number of contemporary art projects, such as the annual show sculpture exhibition, that now has become the Shenzhen Sculpture Biennale. The orientation toward contemporary also emerges from public art projects, conferences, workshops, performing arts festivals, and artist residencies. Among the public art projects are the Shenzhen Overseas Town Subway Murals Project and the 10 Year Public Art Plan for the City of Shanghai Pujiang OCT-PAP. These public art projects are inserted into the urban fabric, attempting to deepen the relationship between artist and audience.

Since its foundation, the museum has also been engaged in research, a necessary step before the realization of any project, of which the exhibition represents only the final stage. A part of the research projects is devoted to the study of individual contemporary artists, and focuses more on those artists whose historicizing process is already ongoing, and can be defined as 'classics'. It is those who were already active in the 1980s whose works have led to significant developments in the history of contemporary Chinese art. So far research has been conducted on the following artists: Zhang Peili, Wang Guangyi, Gu Wenda, Xu Tan, Shu Qun, Wang Jianwei and Sui Jianguo. In the choice of the artists, OCAT museum cannot be considered as unique from other museums, in that it is collecting art from a number of established artists which have become classics.

Nevertheless, its originality can be seen in the new curatorial perspective that is an attempt to create a critical and scientific approach to continue research on individual artists, and the evolution of their artistic language. One of the most interesting exhibitions was Little Movements-Self Practice in Contemporary Art (Xiao yundong: dangdai yishuzhong de ziwo shijian 小运动: 当代艺术中的自我实 践), curated by Liu Ding, Carol Yinghua Lu and Su Wei and held at OCAT in 2011. Little Movements, realized together with Huang Zhuan, former director of OCAT, is an ongoing project that includes research, discussion, publications and exhibitions, and is focussed on artistic, curatorial, institutional and research practices in art history-including not only Chinese but global art. 
The curators, often working together, aim to offer a new narrative alternative to the dominant understanding of art history by exploring artists and artistic practices from the 1980s, 1990s and after 2000. The 'artistic practice' is the central idea of this project, as it starts from the basic idea that art is not merely an object to see, but a process of conceptual investigation generating new meanings. This idea has its roots in the theory of "Global Art" and the Global Art and the Museum GAM Project launched by art historian Hans Belting in 2006. According to this project, after 1989 and in the context of expanding globalization, art history saw new forces shaping art and artistic practices beside artists, critics, curators and art historians. These new forces came from within the art system itself, and can be identified within institutions, art galleries and museums. The Chinese art world is not an exception, and as its value on the art market started to increase, the market itself, auction houses, the new private art museums, collectors, traditional museums, and artists all became part of the same system. This process has inevitably led to a modification of art and its meaning: art now is 'produced' for a consumerist society, rather than 'created'.

The project Little Movements held at OCAT included round-tables on these topics, and videos recording the discussions presented at the exhibition, acting as independent from the art system and the cultural values of the mainstream. It is not an historical retrospective, but aims to highlight the individual practice of art, and from this the name Little Movements, which doesn't mean 'small' in contrast with 'big', but rather concentrates on the individual artist, his role and value in influencing society, culture, etc. The very interesting aspect of this debate that involves young artists and curators is that it has been held inside museums, but at the same time challenges the role of museums within contemporary society, searching for a new role and new critical perspectives, for artists, curators and institutions.

\section{Conclusions}

Today, the art museum system in China is facing different challenges, as highlighted in the paragraphs of this article, and the institution of the museum itself is searching for its own identity. It is located within the contemporary cultural context, it has been accepted within the official institution system, but it also seems to be instrumental to the national cultural policy and acts as a status symbol for companies and individuals. Indeed, in most cases, contemporary art museums are for-profit institutions, managed more like cultural industries than cultural institutions, and most of them collect works without a precise scientific direction or a longterm curatorial plan.

Anther problem with this system is the general approach of founders and managers of museums. Many of them do not have a long-term strategy, because the initial investment does not cover an overall curatorial plan for the future, focussed, for example, on the preservation and research of the permanent collection. To collect contemporary art in China today means to make an investment, representing more of a status symbol than an act of art patronage. It is a way for the new rich to 
acquire legitimacy and obtain "the worship of the nation's (and the world's) heritage of beauty", to use Magnus Fiskesjo's words (Magnus 2015). As a consequence of this, there is a general absence of a systematic permanent collection of contemporary art works, making the museum act more as a kunsthalle, an artistic space devoted to temporary exhibition of works. These aspects reveal a strong contradiction with the primary mission of the museum, which is to research, collect, display works of art and preserve them for future generations.

The context described above would represent an emptying of the meaning of art, which is produced for consumerism and doesn't factor in any debate within society, culture or the art world. The initial questions about the role played by these museums in promoting contemporary art would seem to have but a negative answer: museums are not successfully promoting these new forms of art. But, looking at individual cases, we can discover that there are in the Chinese art world today some artists, curators and museum directors who are trying to explore new ways of conceiving the museum, and are attempting to develop new approaches of exhibiting and curating. One example of this innovative and dynamic approach is the Overseas Contemporary Art Terminal in Shenzhen. This is one of the few and isolated cases of a more critical approach, but still it is not possible to talk about sustainability in the Chinese art museum world. This could be a good place to start to challenge the art world and the institutions within it.

\section{References}

Biennial Foundation. 2002. Guangzhou Triennial. http://www.biennialfoundation.org/biennials/ guangzhou-triennial/. Accessed 20 July 2016.

Cai Nikita Yingqian. 2012. Calling for a process of de-alternativeness: On artists initiatives in China. Yishu: Journal of Contemporary Chinese Art 11 (5): 33-42.

Chen, Guo 陈果. 2015. 49 Luosheng men de Shanghe meishuguan 49 罗生门里的上河美术馆 [Shanghe Art Museum at 49 Luosheng men]. Yishu shije 艺术世界 Art World, 295: 49-51.

Chen, J., Q. Huang, H. Peng, and H. Zhong. 2015. Research report on corporate social responsibility of China. Berlin: Springer.

Chun, Julie. 2014. The Inner Trappings of a Dragon: Long Museum, Shanghai. Yishu Journal of Contemporary Chinese Art 13 (5): 20-28.

De Nigris Ornella. 2016. The infrastructural shift in contemporary Chinese art. Yishu: Journal of Contemporary Chinese Art 15 (1): 56-72.

Fu, Yingying 付瀛荣. 2016. Guanyu meishuguan cangpin denglu zhidu de taolun 关于美术馆藏品登录 制度的讨论 [Discussion on the cataloguing system of art museum collections]. Zhongguo meishuguan qikan 中国美术馆期刊 National Art Museum of China Journal 4: 35-42.

Hua, Jianguo 化建国, and Gao, Min 高敏. 2010. Meishuguan: cong zhanlanguan xiang bowuguan de huigui 美术馆: 从展览馆向博物馆的回归 [Art museum: from exhibiting spaces to museum]. Zhongyuan wenwu 中原文物 Cultural relics from central China 4: 89-91.

Irish, L.E., Jin, D., and Simon, K.W. 2004. China's tax rules for not-for-profit organizations. A study prepared for the World Bank. http://siteresources.worldbank.org/INTCHINA/15030401122886803058/20601839/NPO_tax_En.pdf. Accessed 26 Jan 2018.

Johnson Jeffrey. 2013. The museumification of China. Leap, 18, May 10. http://www.leapleapleap.com/ 2013/05/the-museumification-of-china/. Accessed 25 Jan 2018.

Li, Xianting 栗宪庭. 2007. Shinian yi jue. Cong Dongyu meishuguan dao Hejing meishuguan 十年一觉 - 一从东宇美术馆到和静艺术馆 [Ten years in a while. From Dongyu museum to Hejing 
museum]. http://www.artlinkart.com/cn/article/overview/59cgrxo/genres/critique/JH. Accessed 23 Jan 2018.

Li, Yun 李韵. 2014. Woguo bowuguan shuliang da 4165 jia 我国博物馆数量达 4165 家 [China has reached the number of 4165 museums]. Guangming ribao 光明日报 Guangming daily, 19 May, 1.

Liu, Ding 刘鼎, Lu, C.Yinghua 卢迎华, Su, Wei 苏伟. 2011. Xiao yundong. Dangdai yishu zhong de ziwo shijian 小运动: 当代艺术种的自我实践 Little movements: Self-practice in Contemporary Art. Guilin: Guangxi Normal University Press.

Liu, Lianxiang 刘连香. 2015. Zhongguo bowuguan: zai lu shang 中国博物馆: 在路上 [Museums in China: development and expectations]. Confucius Institute 38 (3): 12-19.

Lu, Tracey L-D. 2014. Museums in China. Power politics and identities. London: Routledge.

Magnus Fiskesjö. 2015. Review essay. The museum boom in China and the state efforts to control history. Museum Anthropology Review 9 (1-2): 96-105.

National Art Museum of China. History. http://www.namoc.org/en/about/history/. Accessed 28 Jun 2016.

O'Doherty Brian. 1999. Inside the White Cube: The Ideology of the Gallery Space (1976). Berkeley and Los Angeles: University of California Press.

Oct Contemporary Art Terminal, OCT is the synonymy of independent art in China, Museum brochure.

Peterson Glen. 2012. Overseas Chinese in the People's Republic of China. London: Routledge.

Shenzhen Art Museum. Meshuguan jianjie 美术馆简介 [Museum presentation]. http://www.szam.org/ about/detail.aspx?id=2. Accessed 25 Jun 2016.

Song, Xiangguang. 2008. The development of private museums in China. Museum International. Ancient China New Museum 237-238: 40-48.

Sun, Shuangjie. 2013. A private matter. http://www.globaltimes.cn/content/809792.shtml. Accessed 20 July 2016.

Today Art Museum. online. Private art museum development forum. Today Art Museum's three past and present directors come together again. http://www.todayartmuseum.com/ennewsdetails.aspx?year= 2013\&id=109\&type=news. Accessed 15 Jan 2018.

Vickers Edward. 2007. Museums and nationalism in contemporary China. Compare 37 (3): 365-328.

Wang, Meiqin. 2008. The Beijing Biennale: the politics of Chinese characteristics. Yishu. Journal of Contemporary Art 7 (4): 20-31.

Wang, Nanming 王南溟. 2011. Yishu zhidu yu falv. Zhongguo yu guoji jiaowang de jieguo 艺术制度与法 律。中国与国际交往的结果 [Art System and Law: the result of exchange between China and International]. Heidelberg: Alte Brucke.

Wang, Yigang 王易罡. 2010. Shi nian: cong dongyu meishuguan dao muqian de Shenyang dangdai yishu 十年: 从东宇美术馆到目前的沈阳当代艺术 [Ten years: from Dongyu Art Museum to the present Shenyang contemporary art]. Wang Yigang Blog, 6 May. http://blog.sina.com.cn/s/blog 4db468440100ty4x.html. Accessed 23 Jan 2018.

Yang, Chao. 2014. A new model exemplifies the art museum boom in China: Yang Chao in conversation with Zheng Shengtian. Yishu: Journal of Contemporary Chinese Art 13 (5): 29-42.

Yang, Xin 杨欣. 2006. Biange yu huiying minyinghua de xingzhengfa longkaijiu 变革与回应: 民营化的 行政法笼开究 [Reform and respond: research on the administrative law in the privatization]. Ph.D. Thesis. Beijing: China University of political science and law. 